\title{
Marbled Crayfish (Procambarus Virginalis) as a Promising Object for Aquaculture Industry
}

\author{
Roberts Jurmalietis \\ DITI \\ Liepaja University \\ Liepaja, Latvia \\ roberts.jurmalietis@liepu.lv
}

\author{
Armands Grickus \\ DITI \\ Liepaja University \\ Liepaja, Latvia \\ armands.grickus@liepu.lv
}

\author{
Ance Elstina \\ DITI \\ Liepaja University \\ Liepaja, Latvia \\ ance.elstina@liepu.lv
}

\begin{abstract}
Marbled crayfish / marmorkrebs, parthenogenetically reproducing decapod crustacean of pet aquarium origin conventionally has been recognized as an undesirable species since it a) is an invasive pest dangerous for aquatic ecosystem resources because of its hardiness, omnivorousness, fast growth, self-cloning abilities; b) has little commercial value for food industry.

However, recently an idea has been introduced about marmorkrebs as a promising cheap protein source, which can help to fight world hunger. Accordingly, research performed at Liepaja University (Latvia) was focused on marbled crayfish farming system design issues. Research paper presented discusses marmorkrebs survival capacities in small-volume microcosm tanks (made from recycled material), under harsh abiotic conditions. Pilot research results obtained will be used to develop experimental project on low-input microcosmic indoor aquaculture for marmorkrebs.
\end{abstract}

Keywords-Crayfish, aquaculture, ecological microcosms

\section{INTRODUCTION}

Inland waters crayfish often belong to environmentally important bionts: they could represent themselves keystone species [1] with a crucial role in aquatic ecosystems functioning and / or can also act as umbrella species for conservation support [2] accordingly, freshwater crayfish must be taken into consideration when managing nature resources. Among European crayfish one particular species, marmorkrebs Procambarus virginalis represents itself a subject of specific interest.

Marmorkrebs or marbled crayfish has received lately a lot of attention from researchers, decision-makers / local authorities, hobby aquarists [3] since this crustacean a) is the only known obligatory parthenogenetic (i.e. asexually reproducing) species among large-sized decapod crustaceans [4], b) originated accidentally ("mysterious" puzzle of rapid speciation) in hobby aquarium environment from slough crayfish Procambarus fallax [5], [6] (crustacean native for southeastern USA), c) has an appealing carapace coloration (which is a key factor for crayfish trade both in case of food consumers and hobby aquarists [7]), and d) possess invasive species capacities - because of its hardiness and high reproductive output (the latter due to asexual propagation mode). Nowadays marmorkrebs successful distribution cases have been already reported for various countries [4].

Despite marbled crayfish has been judged as an undesirable invasive pest, certain food industry focused commercial exploitation is taking place, though. The most popular relevant example is related to Madagascar: since quickly spreading marmorkrebs populations provide a cheap and fast self-renewable food source local people do not care that this alien species is eliminating unique aboriginal aquatic fauna [4]. Similarly, facultatively parthenogenetic spiny-cheek crayfish Orconectes limosus (native for the east coast of USA) is accepted for human consumption in economically suffering European areas despite this invader is dangerous for local aborigenous crayfish species [8], [9]. It should be emphasized that besides harmful influence on indigenous aquatic biodiversity marbled crayfish could threaten also wetland vegetation (e.g. its potentially considerable impact on rice harvest has been discussed [10] ).

The same traits (like fast propagation, hardiness, omnivorousness) which make marmorkrebs to be a successful pest also turn it into a cheap food source promising for world hunger abatement.

In order to use this advantageous resource in a secure way (i.e. without releasing specimens in wild) indoor aquaculture systems with marmorkrebs populations could be developed. As regards to marmorkrebs cultivation know-how there is a wide relevant experience among hobby aquarists since marbled crayfish are quite popular in pet trade (ornamental aquariums) [11], [12]. Still, there are just few evidences about their use in commercial aquaculture industry [4].

Our research performed at Liepaja University focuses on particularly cost-effective aquaculture design for marbled crayfish with strict space-limitations (microcosms), tanks constructed from waste materials, easy available and non-polluting food supply, low temperature environment (i.e. with no need for additional heating); such aquaculture devices could be used first of all for further aquaculture related experimental purposes and for rising marmorkrebs offsprings. 


\section{MATERIALS AND METHODS}

We propose cheap low-maintenance microcosmic aquacultures for marbled crayfish - initial research results will be revealed in this paper presented. The following pilot experiments have been performed:

Experiment \# 1. Waste material recycled for aquarium micro-tank.

PET (i.e. polyethylene terephthalate) plastic bottles recently have been widely reused to design home-made hobby aquariums; still, long term exposure is necessary to judge about possible toxic impact on animals residing in habitats constructed from PET plastic (since relevant literature data are still contradictory, see e. g. [13] and [14]). The following aquarium system has been designed for qualitative experiment: 51 empty PET bottle (previously used for drinking water) has been put in 25 1 aquarium and equipped with small submersible water pump. Aquatic animal community (marbled crayfish, cherry shrimp Neocaridina davidi and guppy Poecilia reticulata) was housed in this tank and PET bottle was used as a biofiltering device: water with waste materials produced by animals have been pumped (recirculating) through this bottle, partially filled with rootless plants (Java moss Taxiphyllum barbieri). Experiment lasted from January 2017 till June 2018. Environmental conditions in experimental tank: water temperature was that of the ambient room temperature $\left(\sim 18-22^{\circ} \mathrm{C}\right)$, illumination: natural light from windows, no bottom sediment (gravel, sand, mud or like) added. About $1 / 4$ of water volume have been exchanged once in a month, animals were fed 3 days a week by Hikari food (diet for fish and invertebrates, popular among hobby aquarists).

Experiment \# 2. Limited space, frugal diet, low temperature environment.

Marmorkrebs single adult specimen has been housed in 51 PET bottle half filled with aged tap water; no air pumping (i.e. oxygen supply and water circulation) provided. Specimen was supplied with black alder (Alnus glutinosa) fallen leaves which served both as a food source and shelter (the latter is a necessary prerequisite for marmorkrebs comfort, see e.g. [15]). This food was chosen because it is easy available / cheap and, according to our preliminary observations, actively consumed by marmorkrebs un has no risky pollution effects on microcosm environment (marbled crayfish are quite sensitive towards saprobic pollution, e.g. previously our experimental micropopulation partially died out when too much boiled vegetable food was added in their tank). Besides limited space, exposure to plastic bottle material and restricted / frugal diet this pilot experiment also included low temperature environment.

The latter was researched since literature data reveal certain contradictions as regards to marmorkrebs relations with coldwater environment. Thus, it has been argued that marmorkrebs as a thermophilic species cannot propagate in low temperature environments and, accordingly, there are restricted possibilities for marbled crayfish to spread within Europe [16], [17] and also to be raised in coldwater aquaculture. Alternatively, there are laboratory experiments which demonstrate that marmorkrebs can withstand low temperature conditions and even successfully reproduce afterwards [18], [19]. Temperature factor is also of academic interest since it has been hypothesized that marbled crayfish as a species originated through thermal (heat or cold) shock on captive slough crayfish eggs [3].

Accordingly, winter time has been chosen for our experiment (it lasted from 29.12.18. till 27.01.19) and aquarium tank was placed on the windowsill outdoors.

\section{RESULTS AND DISCUSSION}

Implementation of marmorkrebs experiments resulted as follows:

Experiment \#1: aquatic animal community survived and even propagated during 19 month long exposure to environment with PET material; accordingly, it appears to be safe to develop small-scale aquaculture in PET bottle tanks. Nevertheless, further research is needed to prove are plastic bottle environment raised animals fully safe for human consumption.

Experiment \#2: marbled crayfish appeared to be submitted to such outdoor ambient air temperatures which reflect mild winter conditions (see Table 1). Despite of stressing ecological factors (space, diet, temperature) marmorkrebs specimen survived and even gave rise to offspring: in 29.12.18 this crustacean was noticed carrying eggs and 6 juveniles were released in 27.01.19 (according to the literature data, single marmorkrebs can have 30400 offsprings per batch [20]). Newborn juveniles were transferred then from experimental coldwater tank to indoor aquarium with water temperature $\sim 20-22^{\circ} \mathrm{C}$ (indoor habitat temperature was increased gradually to ensure marmorkrebs adaptation to temperature change); these crayfish larva successfully grew in the new environment (see Fig.1).

TABLE I. MARMORKREBS COLDWATER EXPERIMENT: AMBIENT AIR TEMPERATURE DYNAMICS

\begin{tabular}{|c|c|}
\hline Date & $\begin{array}{c}\text { Mean daily air } \\
\text { temperature }\left({ }^{\circ} \mathrm{C}\right)\end{array}$ \\
\hline 29.12 .18 & +4 \\
\hline 30.12 .18 & +5 \\
\hline 31.12 .18 & +2 \\
\hline 1.01 .19 & +4 \\
\hline 2.01 .19 & $\begin{array}{c}\text { Storm (marmorkrebs } \\
\text { put indoors) }\end{array}$ \\
\hline 3.01 .19 & Idem \\
\hline 4.01 .19 & +1 \\
\hline 5.01 .19 & +1 \\
\hline 6.01 .19 & +2 \\
\hline 7.01 .19 & +2 \\
\hline 8.01 .19 & +1 \\
\hline 9.01 .19 & +1 \\
\hline
\end{tabular}




\begin{tabular}{|c|c|}
\hline Date & $\begin{array}{c}\text { Mean daily air } \\
\text { temperature }\left({ }^{\circ} \mathrm{C}\right)\end{array}$ \\
\hline 10.01 .19 & 0 \\
\hline 11.01 .19 & +3 \\
\hline 12.01 .19 & +3 \\
\hline 13.01 .19 & +3 \\
\hline 14.01 .19 & +1 \\
\hline 15.01 .19 & +2 \\
\hline 16.01 .19 & +1 \\
\hline 17.01 .19 & +5 \\
\hline 18.01 .19 & +1 \\
\hline 19.01 .19 & +3 \\
\hline 20.01 .19 & +2 \\
\hline 21.01 .19 & +1 \\
\hline 22.01 .19 & -1 \\
\hline 23.01 .19 & -3 \\
\hline 24.01 .19 & -3 \\
\hline 25.01 .19 & -4 \\
\hline 26.01 .19 & -4 \\
\hline 27.01 .19 & -4 \\
\hline
\end{tabular}

\section{CONCLUSIONS}

1. Marbled crayfish Procambarus virginalis predominantly has been recognized as a dangerous invasive species, appreciated only as an object for pet trade and biological research

2. Recently discussions have been started on marmorkrebs utilization for human consumption and, accordingly, research on relevant aquaculture design appears to be urgent

3. Since marmorkrebs belongs to hardy species, there are potentials to develop cost-effective, low-input aquaculture systems to raise this species

4. Our research demonstrates that there are possibilities to sustain marbled crayfish culture within a „frugal" environment: micro-scale tanks (microcosms), plant detritus as a cheap diet, low temperature conditions (i.e. with no additional heating needed).

5. Nevertheless, this was an initial, preliminary study to trigger further research with control and several experimental groups introduced, with more water parameters tested, with crayfish instar morphological examinations and marmorkrebs behaviour observations, etc.

\section{REFERENCES}

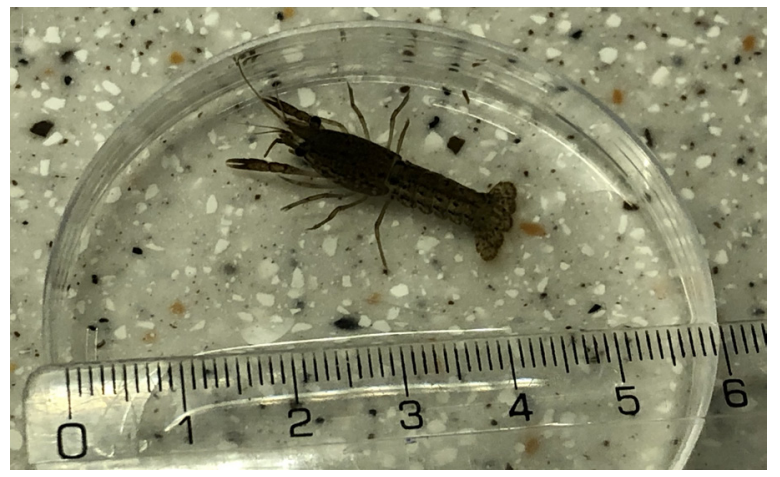

Fig.1 Marmorkrebs juvenile from Experiment \# 2 (07.03.2019)

Our observation coincides with data mentioned above [18], [19], except as regards to reproduction while dwelling in coldwater environment: it has not been described yet.

Pilot experiment also demonstrates that marbled crayfish can survive and propagate on plant detritus diet only (it has been partially supported also by our another experiment where marmorkrebs were fed by fallen alder leaves in the course of 4 months with Hikari food only minute additions once a week; crayfish survived and successfully reproduced). Despite crayfish are omnivorous organisms, there are certain doubts, according to available literature data, about detritus and live plant material to be a sufficient food to meet physiological needs of these crustaceans [21], [22] - additional experimental research is necessary for relevant discussions.

Experiments carried out have been considered as an initial step to implement further marbled crayfish microcosmic aquaculture development related research.
1] J. Gutekunst, R. Andriantsoa, C. Falckenhayn, K. Hanna, W. Stein, J. Rasamy, and F. Lyko, "Clonal genome evolution and rapid invasive spread of the marbled crayfish," Nature Ecology \& Evolution, vol.2, pp. 567-573, March 2018.

[2] J. Reynolds, C. Souty-Grosset, and A. Richardson, "Ecological roles of crayfish in freshwater and terrestrial habitats, "Freshwater Crayfish, vol. 19, No 2, pp. 197-218, 2013.

[3] G. Vogt, C. Falckenhayn, A. Schrimpf, K. Schmid, K. Hanna, J. Panteleit, M. Helm, R. Schulz, and F. Lyko, "The marbled crayfish as a paradigm for saltational speciation by autopolyploidy and parthenogenesis in animals," Biology Open, vol. 4 (11), pp. 1583-1594, Nov 2015. Available: http://bio.biologists.org/content/early/2015/10/23/bio.014241 [Accessed: Dec. 12, 2018], doi: $10.1242 /$ bio.014241

[4] R. Andriantsoa, S. Tönges, J. Panteleit, K. Theissinger, V. C. Carneiro, J. Rasamy, and F. Lyko, "Ecological plasticity and commercial impact of invasive marbled crayfish populations in Madagascar," BMC Ecology, vol. 19 (1), 8, Feb 2019. Available:

https://bmcecol.biomedcentral.com/articles/10.1186/s12898-0190224-1 [Accessed: March 1, 2019], doi:10.1186/s12898-0190224-1

[5] P. Martin, N. J. Dorn, T. Kawai, C. van der Heiden, and G. Scholtz, "The enigmatic marmorkrebs (marbled crayfish) is the parthenogenetic form of Procambarus fallax (Hagen, 1870)," Contributions to Zoology, vol. 79 (3), pp. 107-118, 2010.

[6] F. Lyko, "The marbled crayfish (Decapoda: Cambaridae) represents an independent new species," Zootaxa, vol. 4363, nr 4, pp. 544-552, Dec 2017.

[7] K. Kaldre, K. Haugjärv, M. Liiva, R. Gross, "The effect of two different feeds on growth, carapace colour, maturation and mortality in marbled crayfish (Procambarus fallax f. virginalis)," Aquaculture International, vol. 23, Issue 1, pp. 185-194, Feb 2015.

[8] F. Gherardi and D. M. Holdich, Eds., Crayfish in Europe as Alien Species: How to make the best of a bad situation? Crustacean Issues 11. Rotterdam: Balkema, 1999.

[9] M. Buřič, M. Hulák, A. Kouba, A. Petrusek, and P. Kozák, "A successful crayfish invader is capable of facultative parthenogenesis: a novel reproductive mode in decapod crustaceans," PLoS One, 6 (5), May 2011. Available: https://journals.plos.org/plosone/article?id=10.1371/journal.pone.0020281 [Accessed: Jan. 4, 2019], doi: doi.org/10.1371/journal.pone.0020281 
[10] Z. Faulkes, T. P. Feria, and J. Muñoz, "Do marmorkrebs, Procambarus fallax f. virginalis, threaten freshwater Japanese ecosystems?," Aquatic Biosystems, vol. 8: 13, Jun 2012. Available: https://aquaticbiosystems.biomedcentral.com/articles/10.1186/2046-9063-8-13 [Accessed: Feb. 10, 2019], doi: $\underline{\text { doi. }}$ org/10.1186/2046-9063-8-13

[11] Z. Faulkes, "Marmorkrebs (Procambarus fallax f. virginalis) are the most popular crayfish in the North American pet trade," Knowledge and Management of Aquatic Ecosystems (2015) vol. 416, 20, June 2015. Available: https://www.kmae-journal.org/ articles $/ \mathrm{kmae} / \mathrm{abs} / 2015 / 01 / \mathrm{kmae} 150006 / \mathrm{kmae} 150006 . \mathrm{html}$ [Accessed: Dec. 19, 2018], doi: 10.1051/kmae/2015016.

[12] Z. Faulkes, "The global trade in crayfish as pets," Crustacean Research, vol.44, pp. 75-92, Nov 2015.

[13] F. M. Heindlera, F. Alajmia, R. Huerlimanna, C. Zenga, S. J. Newmand, G. Vamvounise, and L. van Herwerden, "Toxic effects of polyethylene terephthalate microparticles and Di(2- ethylhexyl) phthalate on the calanoid copepod, Parvocalanus crassirostris," Ecotoxicology and Environmental Safety, vol. 141, pp. 298-305, 2017.

[14] A. L. Lusher, P. C. H. Hollman, and J. J. Mendoza-Hill, Microplastics in Fisheries and Aquaculture: Status of Knowledge on Their Occurrence and Implications for Aquatic Organisms and Food Safety. FAO Fisheries and Aquaculture Technical Paper. No. 615. Rome: Food and Agriculture Organization of the United Nations, 2017.

[15] S.A. Jimenez and Z. Faulkes, "Establishment and care of a laboratory colony of parthenogenetic marbled crayfish, marmorkrebs," Invertebrate Rearing, Issue 1, pp. 10-18, 2010.

[16] P. Martin, H. Shen, G. Füllner, and G. Scholtz, "The first record of the parthenogenetic marmorkrebs (Decapoda, Astacida, Cambaridae) in the wild in Saxony (Germany) raises the question of its actual threat to European freshwater ecosystems, "Aquatic Invasions, vol. 5, Issue 4, pp. 397-403, 2010.

[17] A. Lokkös, T. Müller, K. Kovács, L. Várkonyi, A. Specziár, and P.
Martin, "The alien, parthenogenetic marbled crayfish (Decapoda: Cambaridae) is entering Kis-Balaton (Hungary), one of Europe's most important wetland biotopes," Knowledge and Management of Aquatic Ecosystems, Nr. 417, 16, 2016 Available: https://www. kmae-journal.org/articles/kmae/full html $/ 2016 / 01 / \mathrm{kmae} 150095 /$ kmae150095.html [Accessed: Feb. 10, 2019],

doi: doi.org $/ 10.1051 / \mathrm{kmae} / 2016003$

[18] L. Veselý, M. Buřič, and A. Kouba, "Hardy exotics species in temperate zone: can "warm water" crayfish invaders establish regardless of low temperatures?," Scientific Reports, 5, Article number: 16340, 2015. Available: https://www.nature.com/articles srep16340 [Accessed: Feb. 10, 2019], doi: doi.org/10.1038/ srep16340.

[19] K. Kaldre, A. Meženin, T. Paaver, and T. Kawai, "A preliminary study on the tolerance of marble crayfish Procambarus fallax $\mathrm{f}$ virginalis to low temperature in Nordic climate," in Freshwater Crayfish: A Global Overview, T. Kawai, Z. Faulkes, and G. Scholtz, Ed. CRC Press, 2016, pp.54-62 (Chapter 4).

[20] K. Kaldre, "Invasive non-indigenous crayfish species as a threat to the noble crayfish (Astacus astacus 1.) populations in Estonia," $\mathrm{PhD}$ thesis, Estonian University of Life Sciences, Tartu, Estonia, 2018.

[21] W. T. Momot, "Redefining the role of crayfish in aquatic ecosystems," Reviews in Fisheries Science 3 (1), pp. 33-63, January 1995.

[22] J. L. Arredondo-Figueroa, A. Vásquez-González, I. de Los A Barriga-Sosa, C. Carmona-Osalde, and M. Rodríguez-Serna, "Effect of density on growth and feeding of the crayfish Cambarellus montezumae (Saussure, 1857)," Journal of Applied Aquaculture 2010 vol.22 no. 1 , pp. 66-73, 2010. 